\title{
Effect of Air Purifier Use in the Classrooms on Indoor Air Quality-Case Study
}

\author{
Małgorzata Basińska *(D), Michał Michałkiewicz (D) and Katarzyna Ratajczak (D) \\ Institute of Environmental Engineering and Building Installations, Poznan University of Technology, \\ Pl.M. Sklodowskiej-Curie 5, 60-965 Poznan, Poland; michal.michalkiewicz@put.poznan.pl (M.M.); \\ katarzyna.m.ratajczak@put.poznan.pl (K.R.) \\ * Correspondence: malgorzata.basinska@put.poznan.pl
}

Citation: Basińska, M.;

Michałkiewicz, M.; Ratajczak, K. Effect of Air Purifier Use in the Classrooms on Indoor Air Quality-Case Study. Atmosphere 2021, 12, 1606. https://doi.org/ $10.3390 /$ atmos 12121606

Academic Editors: Magdalena Reizer, Zbigniew Nahorski and Jerzy Sowa

Received: 22 October 2021

Accepted: 28 November 2021

Published: 30 November 2021

Publisher's Note: MDPI stays neutral with regard to jurisdictional claims in published maps and institutional affiliations.

Copyright: (C) 2021 by the authors. Licensee MDPI, Basel, Switzerland. This article is an open access article distributed under the terms and conditions of the Creative Commons Attribution (CC BY) license (https:// creativecommons.org/licenses/by/ $4.0 /)$.

\begin{abstract}
Dissatisfaction with indoor air quality is common even in relatively new or renovated Polish school buildings. To improve air quality in educational buildings, portable devices have seen increased use, for which manufacturers guarantee a high level of indoor air purification. However, their optimized operation largely depends on their correct use. The aim of this article was to determine the effectiveness of air purification in a primary school using an air purification device with an analysis of the classroom indoor air quality (IAQ). Two criteria were used, microbiological and particulate matter concentration. Measurements were made before device installation and during its continuous operation, and before and after lessons on chosen days. Measurements related to IAQ did not detect clear differences in the analyzed measurement periods. For microbiological contamination, in the morning before lessons, the total count for all bacteria and microscopic fungi was definitely lower than after lessons. Comparing the periods before and after device installation, no clear tendency for reducing the bacteria count or microscopic fungi occurred during air purifier operation, nor was there any noticeable trend in the reduction of particulate matter. There was no improvement in air quality in the classrooms during the operation of the purification devices.
\end{abstract}

Keywords: indoor air quality (IAQ); school; air purifier device; air purification; microbiological contamination; particulate matter

\section{Introduction}

Indoor air quality plays an important role in human life, as we spend 16-20 h/day inside buildings [1,2]. Most people staying in closed rooms breathe very polluted indoor air, often rich in carbon dioxide, and do not realize that the lack of ventilation and air exchange causes malaise, pain and dizziness, recurring allergies, nausea, drowsiness, or fatigue.

Depending on the age of a building, the people inside are exposed to various physical, chemical, and microbiological pollutants. Physical conditions include temperature and humidity. Chemical impurities include compounds such as carbon dioxide $\left(\mathrm{CO}_{2}\right)$ or nitrogen oxides (NOx). The microbiological pollutants comprise dust, bacteria, and fungi. The appropriate values for all parameters mentioned above contribute to the overall building air quality and help determine the well-being and health of its occupants.

Children are especially susceptible to the harmful biological and chemical factors; hence, the polluted air in schools and kindergartens at which they spend a lot of time (6-8 h/day) can negatively affect their health. Numerous chemicals are emitted from internal room sources [3,4], while respiration from both students and teachers contribute to an increase in the classroom carbon dioxide $\left(\mathrm{CO}_{2}\right)$ concentration $[3,5]$.

Particulate matter is a pollution source that influences indoor air quality and is emitted indoors or out. Microbial contamination can be associated with particulate matter contamination, as microorganism particles can travel into rooms on dust particles.

Sources of biological air pollution include the people staying indoors, fungi found on the building materials, and the external air entering the rooms; those sources of biological 
contamination include bacteria, viruses, pollen, or fungal spores [6-8]. Kwan [9] reported that the dominant source of particulate matter, bacteria, and fungi are indoor emissions. For indoor air PM10 (particulate matter), it's 94\%, for indoor air bacteria, 97\%, and for indoor air fungi, $91 \%$ (a comparison between indoor emissions and ventilation as a source of bacteria and fungi). It follows that indoor emission sources should be controlled to limit the exposure of people in buildings to bacteria and fungi (allergens).

\subsection{Indoor Air Quality in the Schools}

A report by WHO [10] summarized the latest scientific knowledge regarding the relationship between air pollution exposure and adverse health effects in children. Children are exposed to physical, chemical, and biological air pollution both indoors and out. The impact of air quality on children's health has been studied repeatedly. In each case, it was emphasized that identifying the environmental impact of the building is an important learning process factor in schools [11]. Authors [12] conducted studies at schools in Iran which showed that classroom particulate matter concentrations were higher than the external environment. Those schools, as in our case, did not have mechanical ventilation and air conditioning, and the number of students in classes ranged from 14 to 37. Similar findings were reported in [13], a study of internal particulate matter sources and microbiological pollution and their negative impacts on health. Based on this, minimizing internal pollution or installing effective air purifiers should be important for improving indoor air quality and minimizing negative health impacts on children. Similarly, authors Naruka and Gaur [14] established the presence of biological contaminants like bacteria and fungi in schools, some of which pose potential health risks. The humidity of the air was correlated positively with the number of bacteria present.

Due to deteriorating outdoor air quality and increasing concentrations of outdoor particulate matter (PM), natural ventilation in buildings without additional devices for purifying the supply air introduces external particles into buildings and increases the exposure to indoor particulate matter.

\subsection{Methods of Improving Air Quality}

Building air exchange occurs in several different ways, which results in a periodic deterioration of its physical quality. Its performance depends on the weather conditions; therefore, it exhibits seasonal performance. Numerous residential and office buildings, public buildings, schools, nurseries, and kindergartens are located inside old buildings with natural ventilation only. The efficiency of natural ventilation is also affected by the thermal housing of the building or replacement of windows with airtight ones without diffusers. However, all too often, air exchange does not occur.

In numerous works, authors have emphasized that regardless of the building function, the use of supply and exhaust ventilation may be a solution to improve indoor air quality [15]. This solution is often difficult to implement in existing buildings, especially in the educational buildings where natural ventilation is common.

Another method that can have a positive effect on indoor air quality is to ensure good airtightness of the buildings envelope. This prevents contaminated outdoor air from flowing into the building. Regardless of the method and type of ventilation-natural or mechanical one-infiltration occurs in buildings, i.e., the inflow of air from the outside through leaks in the outer envelope. In older buildings, infiltration makes up a large part of the external air supplied due to the high air change rate $(\mathrm{ACH})$ at $50 \mathrm{~Pa}\left(\mathrm{n}_{50}\right)$. In new buildings, including low-energy and passive buildings, the design guidelines are providing a very airtight enclosure to eliminate the effects of air infiltration. In old buildings, the infiltration level is even up to $10 \mathrm{ACH}$, while in passive buildings it is only $0.6 \mathrm{ACH}$. The presented results of the air tightness of the building were obtained using method A presented in the PN EN 13829:2001 standard [16]. Therefore, it should be noted that in older buildings, regardless of the type of ventilation, there is an additional inflow of a large amount of outdoor air (also polluted). 
Another proposal to improve room air quality was presented by Kang [17]. He assessed the effectiveness of solid particle removal from window screen filters. He showed that the particle size removal efficiency of window screen filters varied considerably with increasing particle diameter $(0.3-10.0 \mu \mathrm{m})$, so this type of filter is a possible solution. An alternative solution used to improve school and kindergarten indoor air quality involves installing devices for air filtration and purification. This applied to old buildings in particular and buildings located in places with high outdoor air pollution.

Air purifiers are usually electrical, free-standing or hanging, and used for removal of various impurities based on manufacturer recommendations. Devices available on the market most often use HEPA (High-Efficiency Particulate Air) filters, carbon, ionizing, ultraviolet (UV), catalytic, electrostatic, water, as well as NanoCaptur and plasmacluster technologies. The idea behind these devices stems from the removal of solid particles (particulate matter), cigarette smoke, fragrances, some harmful gases, viruses, bacterial/fungal spores, and allergens, as well as humidity regulation in the room. According to the manufacturer, the effectiveness of air purification from viruses, bacteria, fungi, and gases ranges from 80 to $99.5 \%$. Kolaris presented a proposal to evaluate the effectiveness of air purifiers [18] in which he presented his assessment of an air purifier based on photocatalytic oxidation (PCO). The authors took as a criterion the reduction of dust and microbial contaminants.

\subsection{Research Goal}

Recently, air purifiers have been installed in many schools, kindergartens, and nurseries in Poland. When choosing a given technical solution, decision-makers are mainly guided by the price and the working effectiveness given by manufacturers, determined in laboratory conditions. This project sought to determine how well a given type of purifier behaved in real working conditions. The second aim of the study was to assess the effectiveness of air purifiers installed in two classrooms. A novelty in the research is the use of microbiological contamination indicators to assess the effectiveness of air purifiers. In air quality research, attention is paid mainly to chemical contamination, which is the concentration of $\mathrm{CO}_{2}$.

This paper discusses the results of a new air purifier type that entered the Polish market. Before conducting these measurements, the authors did not find any scientific publication which reported information regarding the effectiveness of ionization and electrostatic attraction of a charged particles air purifier.

Three criteria were used to establish that effectiveness: carbon dioxide concentration, number of suspended particulate matter particles, and the number of bacteria and fungi. Measurements were made at the beginning of the day before switching on the devices, during its continuous operation, and before and after classes on chosen days. Test results were compared to Polish Standard guidelines, which specify the degree of microbiological and physical air pollution in buildings (PN-89/Z-04111.02 [19], PN-89/Z-04111.03 [20], PN-EN ISO 14644-1 [21], PN-EN 16798-1 [22]).

\section{Materials and Methods}

\subsection{Buildings Characteristics}

A typical primary school located in Swarzędz, in the Greater Poland region, was selected for these studies. It is in a town with an area of $8.2 \mathrm{~km}^{2}$ and a population of $\sim 31,000$ that results in one of the highest population densities among Polish cities (3730 people $/ \mathrm{km}^{2}$ ). In Poland, in the 1960s to 1980 s, all schools were built according to one technical design. The school consisted of three parts. The central part adjacent to the gym has three usable floors (ground floor and two floors). In classrooms with areas between 60 and $70 \mathrm{~m}^{2}$, the windows are plastic. The facility has radiator heating with fin radiators and thermostatic radiator valves. There is no mechanical ventilation in the classrooms. The building exchanges air through natural ventilation (mainly ventilation grilles with 
dimensions of $15 \times 15 \mathrm{~cm}$ ) connected to vertical ventilation shafts that lead the air above the roof.

\subsection{Classrooms Characteristics}

Two typical classrooms, one located on the ground floor (classroom 04), one on the first floor (classroom 105), and a measuring point located on the sidewalk $\sim 5.0 \mathrm{~m}$ from the front wall of the building in front of the school were selected for research.

Table 1 summarizes the basic parameters of classrooms.

Table 1. Characteristics of the studied classrooms.

\begin{tabular}{ccc}
\hline Parameter/Feature & Classroom 04 & Classroom 105 \\
\hline Location & Ground floor & 1 st floor \\
Area $\left(\mathrm{m}^{2}\right)$ & 64.2 & 67.7 \\
Cubature $\left(\mathrm{m}^{3}\right)$ & 202 & 213 \\
Glazing surface $\left(\mathrm{m}^{2}\right)$ & 11.7 & 11.5 \\
Area per person $\left(\mathrm{m}^{2} /\right.$ person $)$ & $2.2-32.1$ & $2.6-33.9$ \\
Ventilation & 2 ventilation grilles $(15 \times 15 \mathrm{~cm})$ & \\
& and 1 ventilation grille above the & 2 ventilation grilles $(15 \times 15 \mathrm{~cm})$ \\
\hline
\end{tabular}

\subsection{Characteristics of Air Purifiers}

To improve room air quality, one portable air purifying device was installed in each classroom. Measuring devices $390 \times 450 \times 1470 \mathrm{~mm}$ (weight approx. $55 \mathrm{~kg}$ ) were placed on the floor in the rear of each classroom. The purifier technology combines two processes, air ionization and electrostatic attraction of charged particles. The ionized particles that enter the purification chamber settle on the inner surface, which is automatically washed (rinsed with water from the internal tank) once a week. The strong electric field inside the device deactivates and eliminates microorganisms (bacteria, fungi, and viruses, as well as their DNA, RNA, toxins and other proteins), mold spores, animal hair fragments, and soot from traffic or industrial plants. In addition, this patented device was equipped with activated carbon filters that removed gases including ozone, smoke, and odors. According to the technical specifications provided by the manufacturer, the device has a cleaning capacity of $100-250 \mathrm{~m}^{3}$ of air per hour. It can be used in rooms with areas $<100 \mathrm{~m}^{2}$, works from 0 to $60{ }^{\circ} \mathrm{C}$ and relative humidity levels from 0 to $100 \%$; it effectively removes viruses, bacteria, fungi, and gases from the air. The effectiveness of the air purification system can reach $99.5 \%$ of ultrafine particles that are harmful to human health when inhaled. According to the manufacturer, the advantages of the device include:

- Cleans and re-circulates the workspace air;

- Removes pollutants, chemicals, and biological matter from the air;

- Entrapment of nano-sized particles which readily pass easily through HEPA filters;

- Reduction of asthma and allergy symptoms;

- Reduction of work absenteeism;

- Increase of productivity and suitability for poorly ventilated premises.

\subsection{Measurments}

The assessment of indoor air quality (IAQ) in classrooms and the outdoor environment (outdoor air quality-OAQ) included periodic and continuous measurements of air temperature $\left({ }^{\circ} \mathrm{C}\right)$, relative humidity $(\%)$, carbon dioxide concentration (ppm), atmospheric pressure $(\mathrm{hPa})$, and the number of suspended particulate matter particles divided into fractions. Measurements of indoor and outdoor air quality were performed using an ALMEMO 2890-9 air quality recorder with sensors, temperature accuracy of $\pm 0.2{ }^{\circ} \mathrm{C}$, relative humidity accuracy of $\pm 0.2 \%$, and carbon dioxide concentration accuracy of $\pm 50 \mathrm{ppm}$. A particle number meter (Fluke) was used for particulate matter measurements. Continuous measurements of the physical air quality were carried out at two-minute time intervals and averaged to hourly values. All dust particle measurements at a given station were 
conducted in quadruplicate. The results of the dust fraction occurring in the air were presented as cumulative values, i.e., the given fraction result includes all particles that are equal to or higher than the particle sizes in a given range.

The scope of microbiological air contamination testing included collecting air samples $\left(50-100 \mathrm{dm}^{3}\right.$ ) by means of collision using the MAS-100 Eco sampler (from Merck) and determination of the following microorganisms-the total number of mesophilic and psychrophilic bacteria, the number of mannitol-positive $(\mathrm{M}+)$ and mannitol-negative $(\mathrm{M}-)$ Staphylococcus, the number of Actinobacteria and Pseudomonas fluorescens, and the total number of microscopic fungi. The number of colony forming units (CFU) which grew on the Petri dishes in culturing period was corrected using the Feller statistical conversion table [23], and the result was converted into the number of colony forming units presented in $1 \mathrm{~m}^{3}$ of air $\left(\mathrm{CFU} / \mathrm{m}^{3}\right)$.

A detailed description of the measuring devices, research methods, microorganism cultivation, and Polish Standards used for physical and microbiological air quality assessment is presented in previous works [5,24]. In addition, records of the presence of children and guardians were kept in the rooms, and the opening/closing times of windows to ventilate the rooms was recorded (manual entry). During the research, a recommendation was issued not to open the windows on chosen days. This was to limit the influence of uncontrolled factors connected with air flow.

\subsection{Measurment Period}

Microbiological and physical air quality tests were performed to assess the air quality in the educational building. The air samples for microbiological tests and air pollution measurements with suspended particulate matter particles were carried out in the morning, before lessons, and in the afternoon, after classes. Additionally, outdoor air quality measurements were conducted in front of the school during the same period. The research was carried out in two stages. The initial research period ( 15 April) was carried out with typical classroom functionality without additional air purifying devices, while the second period (18 April to 17 June) included tests in classrooms with installed air purifiers. The physical and microbiological air qualities were measured immediately before the installation of air purifiers in the afternoon on 15 April. During the main research period, from 15 April to 23 June, the devices installed in the classrooms worked during lessons. Due to the need to obtain accurate results of the physical air quality, recorders and sensors were installed in classrooms and in the external environment on 6 May for a continuous ( $24 \mathrm{~h} /$ day) measurement of air quality with two-minute measurement intervals $\left(\mathrm{CO}_{2}\right.$ concentration, relative humidity, temperature, atmospheric pressure). In addition, throughout the two-month period of air purifier operation, teachers completed prepared surveys detailing lesson start and end times, the number of people in the room, opening and closing of windows and doors, and any other events that might affect the measurements.

\section{Results}

\subsection{Physical Measurements}

Although air purification devices do not change the concentration of carbon dioxide, the article presents the concentrations recorded in the classrooms, because this parameter, apart from temperature and relative air humidity, is one of the basic measures of physical air quality parameters [21,22] and it can be used to assess the air exchange in the room. High $\mathrm{CO}_{2}$ concentration may indicate improper air exchange in a given room. The statistical analysis of the measurement results of the basic physical air quality parameters is presented in Table 2. The results are divided into days during which students stayed at school (working day, Monday to Friday-Mon-Fri) and days off (weekend, Saturday to SundaySat-Sun). All measurements were carried out during the continuous operation of devices for the indoor air purification installed on 15 April. 
Table 2. Statistical analysis of air quality measurements- $\mathrm{CO}_{2}(\mathrm{ppm})$, temperature $\left({ }^{\circ} \mathrm{C}\right)$, and $\mathrm{RH}(\%)$.

\begin{tabular}{|c|c|c|c|c|c|c|}
\hline \multirow{2}{*}{ Parameter } & \multicolumn{2}{|c|}{ Classroom 04} & \multicolumn{2}{|c|}{ Classroom 105} & \multicolumn{2}{|c|}{ Background Research } \\
\hline & Mon-Fri & Sat-Sun & Mon-Fri & Sat-Sun & Mon-Fri & Sat-Sun \\
\hline \multicolumn{7}{|c|}{ Carbon dioxide concentration (ppm) } \\
\hline & \multicolumn{6}{|c|}{ Lesson hours (8:00-15:00) } \\
\hline mean & 1037 & 434 & 811 & 382 & 412 & 394 \\
\hline standard deviation & 340.2 & 5.0 & 254.1 & 5.6 & 31.0 & 14.0 \\
\hline $\max$ & 2831 & 544 & 2481 & 495 & 838 & 439 \\
\hline \multirow[t]{2}{*}{$\min$} & 383 & 373 & 342 & 341 & 345 & 350 \\
\hline & \multicolumn{6}{|c|}{ Hours before and after lessons } \\
\hline mean & 486 & 434 & 416 & 379 & 438 & 440 \\
\hline standard deviation & 116.4 & 15.7 & 74.1 & 13.2 & 41.0 & 43.0 \\
\hline $\max$ & 2169 & 611 & 1796 & 539 & 971 & 584 \\
\hline min between & 367 & 369 & 329 & 333 & 345 & 351 \\
\hline \multicolumn{7}{|c|}{ Air temperature $\left({ }^{\circ} \mathrm{C}\right)$} \\
\hline & \multicolumn{6}{|c|}{ Lesson hours (8:00-15:00) } \\
\hline mean & 25.9 & 25.0 & 27.0 & 27.1 & 23.6 & 23.7 \\
\hline standard deviation & 0.7 & 0.3 & 0.6 & 0.4 & 2.4 & 2.0 \\
\hline $\max$ & 29.0 & 28.0 & 30.2 & 29.7 & 37.7 & 41.0 \\
\hline \multirow[t]{2}{*}{$\min$} & 21.9 & 23.0 & 23.4 & 25.0 & 9.3 & 8.9 \\
\hline & \multicolumn{6}{|c|}{ Hours before and after lessons } \\
\hline mean & 25.4 & 25.3 & 26.0 & 26.2 & 18.0 & 17.7 \\
\hline standard deviation & 0.9 & 0.6 & 0.5 & 0.4 & 4.4 & 4.5 \\
\hline $\max$ & 29.4 & 29.0 & 30.0 & 29.3 & 42.6 & 41.1 \\
\hline min between & 17.2 & 23.0 & 23.4 & 23.9 & 6.1 & 6.9 \\
\hline \multicolumn{7}{|c|}{ Relative humidity (\%) } \\
\hline & \multicolumn{6}{|c|}{ Lesson hours (8:00-15:00) } \\
\hline mean & 45.8 & 42.9 & 41.7 & 37.7 & 43.5 & 40.3 \\
\hline standard deviation & 4.1 & 0.7 & 3.4 & 0.9 & 12.8 & 10.6 \\
\hline $\max$ & 68.3 & 50.2 & 66.3 & 44.3 & 92.9 & 88.0 \\
\hline \multirow[t]{2}{*}{$\min$} & 21.6 & 31.4 & 21.3 & 28.7 & 13.7 & 15.8 \\
\hline & \multicolumn{6}{|c|}{ Hours before and after lessons } \\
\hline mean & 43.6 & 43.0 & 40.3 & 39.4 & 64.1 & 60.8 \\
\hline standard deviation & 4.3 & 1.6 & 4.1 & 1.1 & 16.1 & 16.1 \\
\hline $\max$ & 68.2 & 51.8 & 68.9 & 45.3 & 95.1 & 95.0 \\
\hline min between & 24.1 & 28.2 & 21.3 & 28.8 & 10.0 & 9.2 \\
\hline
\end{tabular}

During the lesson hours (8:00-15:00), there were periodic exceedances of the carbon dioxide concentration. In classroom 04, the average value was $1037 \mathrm{ppm}, 811 \mathrm{ppm}$ in classroom 105, and $412 \mathrm{ppm}$ outdoor. The highest values were recorded in classroom 04 (2831 ppm), which puts the facility in air purity category IV (PN-EN 15,251 [25]). A slightly lower maximum value (2481 ppm) occurred in classroom 105 . According to the surveys conducted by teachers, the windows were opened in both rooms during lessons. The problem in Polish schools is insufficiently working natural ventilation. Hence, the opening of windows occurs in order to improve IAQ. It is a common phenomenon in these facilities. This led to the conclusion that the air quality deteriorated significantly when the windows were closed. In the hours without lessons and on non-school days, the average carbon dioxide concentration level was much lower and varied from 379 to $486 \mathrm{ppm}$. The outdoor $\mathrm{CO}_{2}$ concentration remained consistent throughout the measurement period at approximately $420 \mathrm{ppm}$. This helped improve the quality of the indoor environment. The air temperature in the classrooms before, during, and after lessons was more often higher in classroom 105, with south-facing windows. According to local requirements [25], the maximum temperatures $\left(28.0-30.2{ }^{\circ} \mathrm{C}\right)$ classified the rooms into the lowest air quality category (IV). The average relative humidity ranged from 37.7 to $45.8 \%$ throughout the measurement period. Those values were within acceptable limits. 
A graphical interpretation of the variability of the main physical air quality parameters, $\mathrm{CO}_{2}$, for the selected week (6 June to 12 June) is shown in Figure 1. The charts also include other parameters relevant to these measurements, such as the number of people in the room (gray vertical stripes) and the variability of a given external parameter, background research (dotted line). Based on those results, the following trends were observed:

- the influence of window opening on the improvement of the physical air quality;

- increase of temperature and carbon dioxide concentration while students are in the room;

- higher indoor carbon dioxide concentrations relative to the outdoor air concentration;

- lower-range relative humidity levels in classrooms relative to outdoor air.

(a)



(b)

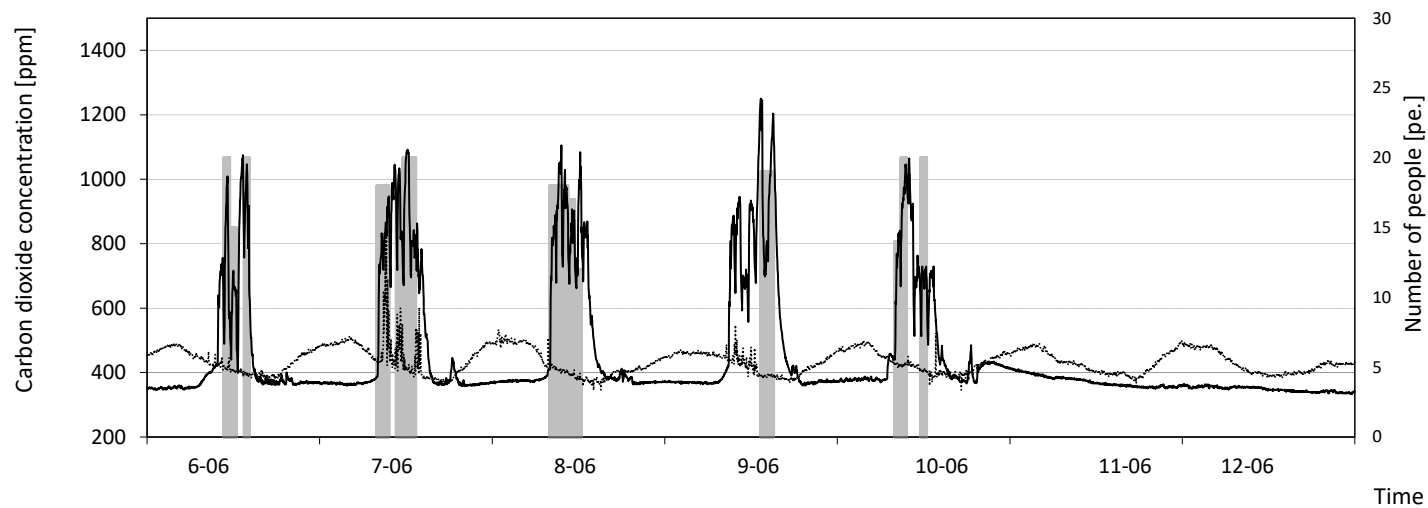

Figure 1. Variability of carbon dioxide concentrations in the week from 6th to 12th June, (a) in classroom 04 , (b) in classroom 105.

\subsection{Particulate Matter Measurements}

During the first test day (15.04.), no air purifier was installed in the classrooms, while the other tests were carried out with continuous operation of the air purifier.

When assessing the room air quality after device installation, the number of suspended particulate matter particles indicated the smallest fraction $(0.3$ and $0.5 \mu \mathrm{m})$ at all measuring points and in all research periods was most numerous in the morning before lessons. The number of larger particles (from 1.0 to $10.0 \mu \mathrm{m}$ ) increased after lessons. The indoor/outdoor (I/O) dust particle ratio was determined for individual measuring points to express the change in the number of dust particles and the level of air exchange in the rooms. The average I/O ratio before lessons was 0.37 for classroom 04 and 0.34 for classroom 105; this ratio increased significantly after lessons (classroom 04-0.86, classroom 105-1.01). A previous study conducted at another school showed that in winter this indicator after 
lessons reached an even higher level of 1.86 [24]. The significant difference in our results was due to teachers ventilating the classrooms by opening the windows (by airing) very often during the measurement period, thus improving the air quality in terms of $\mathrm{CO}_{2}$ concentration. The ratio of dust particles in the indoor and outdoor air in the classrooms before and immediately after lessons is presented in Figure 2.

(a)

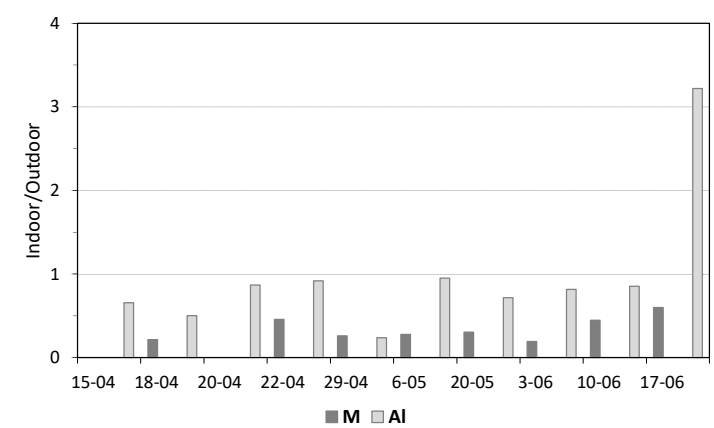

(b)

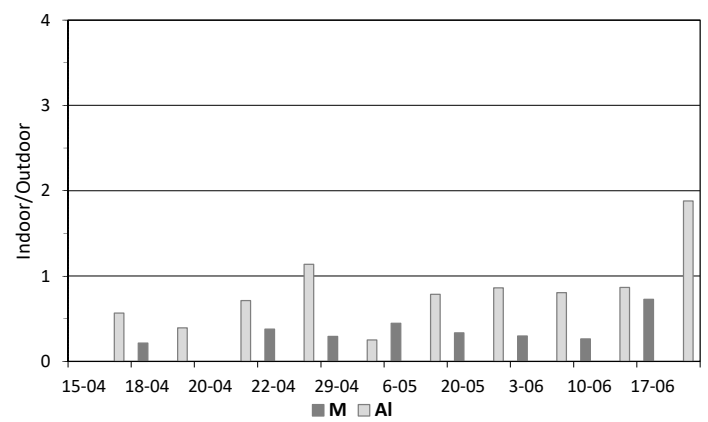

Figure 2. The indoor/outdoor ratio of the number of suspended particles in the morning (M) and after lessons (Al), (a) in classroom 04, (b) in classroom 105.

\subsection{Microbiological Measurements}

The bacterial and microscopic fungi study results indicated that regardless of whether an air purifier was installed, the number of all microorganisms was usually higher after the lessons ended than before class. The lowest fluctuations in the number of microorganisms occurred for Pseudomonas fluorescens, Actinobacteria, and mannitol-positive (M+) Staphylococcus.

The highest microorganism increases after lessons were observed for mannitol-negative (M-) Staphylococcus, mesophilic bacteria, and psychrophilic bacteria, as well as periodically among microscopic fungi. Because windows (ventilating) were opened during lessons and breaks between the lessons, the quality of indoor air could have been affected by the degree of microbial pollution from the outdoor air. However, a comparison between test results from the classrooms and the outdoor air indicated that the number of bacteria and microscopic fungi outside was higher than in classrooms in a few cases. This was especially evident in the mornings, before lessons, when the windows were not opened. After lessons, significant pollution from psychrophilic bacteria and microscopic fungi was found on 18 April and at the end of May and June. For the outdoor air, regardless of the date or time of day (in the morning, before or after lessons, before or after classroom air purifier installation), the number of tested microorganisms (bacteria and microscopic fungi) fluctuated significantly. Based on the calculated averages of individual bacteria and microscopic fungi $\left(\mathrm{CFU} / \mathrm{m}^{3}\right)$ on all study dates, only the average number of mannitol-positive $(\mathrm{M}+)$ Staphylococcus in classroom 04 and the average number of Pseudomonas fluorescens in classroom 105 was lower after lessons. In the outside air, however, an increase in the average number of Pseudomonas fluorescens and Actinobacteria was noted after lessons (Figure 3). 
(a)

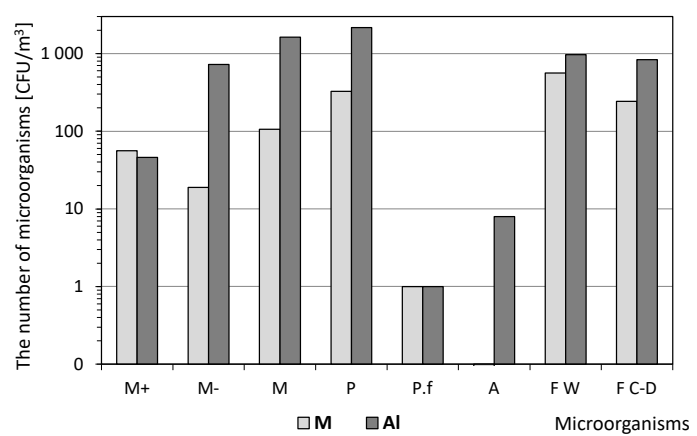

(c)

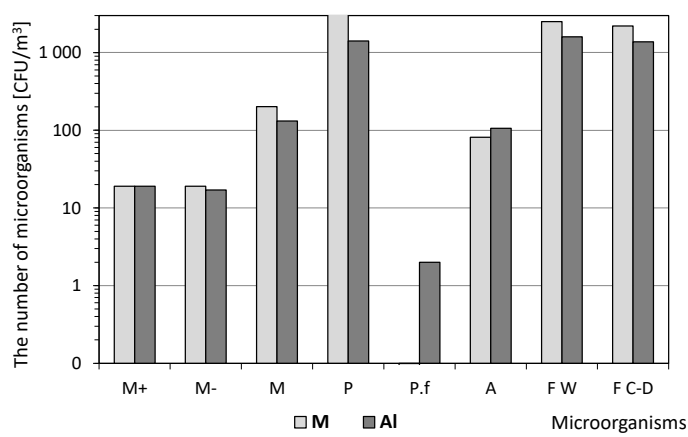

(b)

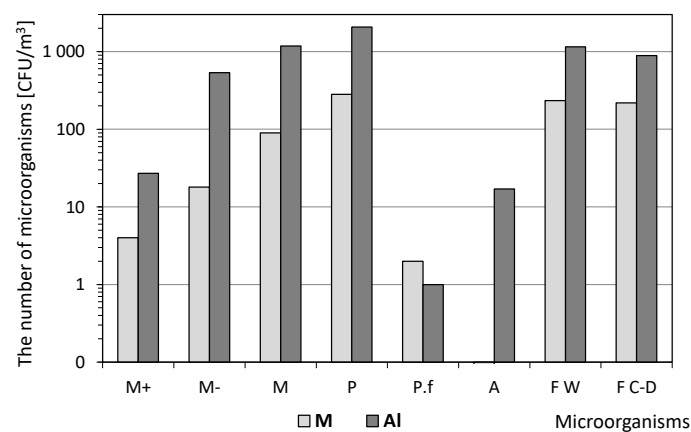

Figure 3. Average number of bacteria and microscopic fungi in the morning (M) and after lessons (Al), (a) in classroom 04, (b) in classroom 105, (c) outdoor air (research background). M+-mannitol-positive Staphylococcus; M--mannitol-negative Staphylococcus; M-mesophilic bacteria; P-psychrophilic bacteria; P.f-Pseudomonas fluorescens; A-Actinobacteria; F Wmicroscopic fungi on Waksman medium; F C-D—microscopic fungi on Czapek-Doxa medium.

These values indicated that people (children and teachers) staying in these rooms were the main source of microbial air pollution and that the periodic inflow of external air when the windows were open did not affect indoor air pollution. Notably better microbiological air quality in the morning (before lessons) resulted from cleaning the classroom in the afternoon after taking air samples for microbiological tests. This cleaning involved dry sweeping and wet floor cleaning. The tops of the benches were also wet wiped, and chairs placed upside down on them, so the floor surface could be cleaned thoroughly. As a result, both particulate matter and microorganisms that settled on the floor and benches were collected. The clean classroom with the windows closed (after cleaning and at night) was thus prepared to start lessons. This period ranged from 17 to $18 \mathrm{~h}$ and there were no people in the room at that time. Comparing the period before and after installing the air purification device, there was no clear downward trend in both bacterial and microscopic fungus numbers when the air purifier was in operation. Therefore, there was no significant improvement of the microbiological air quality in classrooms. Additional identification of microorganisms indicated that the cultured microorganisms are a natural saprophytic microflora of the air environment. The mesophilic and psychrophilic bacteria included, e.g., Leuconostoc mesenteroides, Staphylococcus cohnii, Staphylococcus simulans, micrococci (Micrococcus sp.), and aerobic spore rods (Bacillus sp.). Based on the Polish Standard [19], which sets the level of microbial air pollution, the air is not polluted with bacteria when the total number of mesophilic bacteria in $1 \mathrm{~m}^{3}$ of air was less than $1000 \mathrm{CFU}$, there were no mannitol-positive (M+), mannitol-negative (M-) Staphylococcus, and Pseudomonas fluorescens, and the number of Actinobacteria is lower than $10 \mathrm{CFU}$. When the total number of mesophilic bacteria ranged from 1000 to $3000 \mathrm{CFU}$, the maximum number of Pseudomonas 
fluorescens remained at $50 \mathrm{CFU}$ and below, the number of Actinobacteria ranged from 10 to $100 \mathrm{CFU}$, the maximum concentration of (M+) Staphylococcus did not exceed $25 \mathrm{CFU}$, and $(\mathrm{M}-) 50$ was less than $\mathrm{CFU}$, then air pollution is considered moderate. Any bacteria level higher than those specified above indicated strongly polluted air. However, for microscopic fungi, moderately clean air [20], especially in the late spring and early autumn periods, occurs when the number of fungi is 3000-5000 CFU. With levels between 5000 and $10,000 \mathrm{CFU}$, pollution may have negative effects on the natural environment of man. Levels that exceed the upper limit of 10,000 CFU indicate pollution that poses a human threat.

The high numbers of $(\mathrm{M}+)$ and $(\mathrm{M}-)$ Staphylococcus after lessons in both classrooms indicated that the air was most often heavily contaminated with these bacteria. The concentrations of mesophilic bacteria after lessons most often indicate moderately polluted air, as does the periodic presence of Actinobacteria. Pseudomonas fluorescens usually did not occur in classrooms; hence, its numbers usually indicated clean air. Despite a clear increase in the number of microscopic fungi after lessons, their number in classrooms sporadically exceeded the value of $3000 \mathrm{CFU} / \mathrm{m}^{3}$, which suggested that the air was, on average, clean. On the other hand, outdoor showed occasional medium or strong air pollution from the presence of Actinobacteria and Staphylococcus, while the number of microscopic fungi only sporadically indicated pollution that could have a negative impact on the environment or posed a threat to humans. The remaining bacteria usually indicated uncontaminated air.

Psychrophilic bacteria, not listed in the Polish Standards, were present both in classrooms and in outdoor air, often in higher numbers than mesophilic bacteria. This natural microflora of the air environment also indicated the ineffectiveness of removing fine particles by the air purifier installed in classrooms.

The microbiological evaluation results before lessons, in the morning (M), and after lessons (Al) in both classrooms are summarized in Tables S1 and S2, while the outdoor results (background research) appear in Table S3. Table S3 (next to the research data) gives the operational period of the air purifier, although it did not affect the outdoor air quality near the school.

\section{Discussion}

Poor indoor air quality, which is a serious problem in schools due to the large number of students in the classroom, and insufficient internal air exchange, were reported by Andualum et al. [26]. Similar to our study, those authors noted a clear increase in bacterial numbers after classes, and that temperature, relative humidity, and dust concentrations were associated with bacterial contamination. Other authors $[27,28]$ emphasized the influence of the school location and the impact of air pollution on the respiratory impairment and neurodevelopment in children. The results of our research at a school located directly next to a street, in late spring, did not confirm the significant impact of the external air on the degree of classroom contamination, e.g., during ventilation, because most of the analyzed physical and microbiological parameters in the external environment were lower than inside the building, especially during lessons. Our research did not show such diverse microorganisms, and the vast majority belonged to natural saprophytic microflora in the air.

In Poland, the air quality was also tested with a particular focus on the carbon dioxide concentration, temperature, relative humidity, solid particles, bacteria, and fungi [29]. The results of microclimatic measurements were very similar to our results; the concentrations and types of bacteria detected partially corresponded to our tests and periodically exceeded the permissible values specified in Polish Standards and recommendations. In addition, pathogenic and highly sensitizing forms were found among the detected microorganisms. Du et al. [30] reported that the use of a high-efficiency HEPA air filter placed in the bedroom of a child with asthma reduced the PM concentration by an average of 69 to $80 \%$, but there was no decrease in the $\mathrm{CO}_{2}$ concentration. The studies of Van der Zee et al. [3] regarding the use of a new mechanical ventilation system with a fine F8 (MERV14) filter in classrooms yielded a $30 \%$ to $48 \%$ decrease in particle number (PM). They found that the influence of an air filtration system on classroom air quality varied depending on the ventilation 
characteristics of the building, usage profile, outdoor pollution concentration, season, and climatic conditions. Smythe [31] demonstrated that particle air purifiers (PAPs) effectively removed PM2.5 particles associated with respiratory diseases in children. As a result, PAPs can be useful for reducing exposure to internal air pollutants. Our studies did not show such efficiency of air cleaning from solid particles. Perhaps the mechanism of action of the purifier used in our studies, based on air ionization and electrostatic attraction of charged particles, does not work in rooms such as classrooms. The manufacturer states that the effectiveness of air purification from viruses, bacteria, fungi, and gases ranges from 80 to $99.5 \%$. Unfortunately, such reductions in bacteria and fungi were not noted, whereas for gases, the authors monitored carbon dioxide $\left(\mathrm{CO}_{2}\right)$ levels, which were definitely higher when children were present than before lessons, as well as higher than outdoor air. Based on the microorganisms detected, both before (most often in smaller concentrations) and after lessons, as well as large fluctuations in the number of particles in the air, we concluded that those particles came primarily from students in the classrooms and the outside air, introduced into the classrooms when airing them out. The method of cleaning classrooms and the relatively poor air exchange through the ventilation system may have an additional impact on air pollution and was confirmed by concentration measurements. Our research was conducted during the end of spring (May and June). The average outdoor air temperature in the measurement period was $18 \pm 4.4^{\circ} \mathrm{C}$, and the maximum was recorded at the level of $24.6^{\circ} \mathrm{C}$.

There is no air conditioning in Polish schools. In order to lower the internal air temperature in the classrooms, teachers open windows. As it was shown in such conditions, air purifiers did not fulfill their role. Their operation did not make the amount of particulate matter in the indoor air low (as low as before the start of the lesson). Intensive airing of the rooms did not reduce air pollution after the end of the lesson. If the purifiers were effective, they should be able to remove the incoming particulate matter.

This indicated that the air purifier did not fulfil its role, and that children staying in the classrooms for several hours were the source of the microbiological and physical pollution.

As shown by the results concerning the concentration of PM10 in Poznań [32], in June-August, the particulate matter concentration is below $5 \mu \mathrm{g} / \mathrm{m}^{3}$. In May and September, the concentration is below $20 \mu \mathrm{g} / \mathrm{m}^{3}$. In the other months, values are significantly higher, up to $100 \mu \mathrm{g} / \mathrm{m}^{3}$. It may therefore turn out that in the case of air quality measurements in winter, the results obtained in the analyzed school could be even worse. So, despite the operation of air purifiers, the amount of particulate matter in the indoor air could be even higher. Such a situation took place and has been confirmed by other research that was carried out in nurseries located in the same agglomeration as the studied school [33]. Although the research concerned facilities for smaller children, they can be treated as comparable, because nurseries are also facilities where a large number of people stay in a relatively small area. The results of the research showed that in winter, the quality of indoor air in the range of PM concentration is bad, because the concentration of PM in the outdoor air is high. At the same time, it was shown that in the comparable period to the analyzed period at school (June), the particulate matter concentration in the outdoor air was low, which meant that it was also low indoors.

To summarize, we established that:

- Despite recommendations, the windows in the rooms were open most of the day (the door was also often open as well), which resulted in increased air exchange. This situation is typical in educational buildings with insufficient natural ventilation.

- Opening windows in the rooms caused a sharp decrease in $\mathrm{CO}_{2}$ levels, in many cases those levels approached the concentration of outdoor air (approx. $350 \mathrm{ppm}$ ). Despite this, in room 04 there were periods when $\mathrm{CO}_{2}$ levels exceeded $2800 \mathrm{ppm}$ (2500 ppm in room 105), which placed this facility into air purity category IV.

- The $\mathrm{CO}_{2}$ concentration in classrooms without students equilibrated with outdoor air-two hours after the end of lessons and after cleaning the room.

- Temperature measurements over 24-h periods indicated that the rooms overheated. 
- Based on microbiological test results, the classroom air is more polluted in terms of selected microorganism groups. Higher concentrations of mesophilic bacteria and staphylococci, which originate from the people in classrooms, pose the greatest danger to the health of students.

- Identification of microorganisms indicated the presence of opportunistic, allergenic, and potentially pathogenic bacteria in the air.

- Particulate matter concentrations placed these rooms in the lowest air quality class [23].

- There was no air quality improvement in the classroom during the air purification device operation.

The reason for the ineffectiveness of the air purifiers could be their inappropriate use. According to the technical data, the rate of air exchange by the device is at the level of 0.5 to $1 \mathrm{ACH}$, which, in the case of rooms with a high people density and high degree of pollution, may be insufficient. When using such technical solutions that may have an impact on IAQ, their performance should be adapted to the size and use of the rooms [34]. Because the air purifiers did not reliably clean the polluted outdoor air entering the rooms [35], other solutions require development or examination. Potential solutions may include a forced air supply, which allows pretreatment of the air by filtration [34]. Air purifiers can act as secondary purification in support of filtration used in forced ventilation systems.

\section{Conclusions}

This project yielded the following general conclusions:

- Although this project represents an individual case, these results may refer to numerous typical educational buildings that seek to improve air quality and ensure the comfort of students and teachers.

- Assessment of air quality and its purification degree should consider physical qualities (temperature, humidity, $\mathrm{CO}_{2}$, particulate matter), but, more importantly, microbiological quality.

- Using the trends related to the idea of air purification in schools, attempts were made to offer devices that do not improve the microbiological and PM quality of the air.

- The actual efficiency of the air purifier may differ significantly from what the manufacturer declares. The proper choice of device, individual for each classroom, plays a major role in this.

- Before using the device for air purification in large-volume, high-density rooms, its effectiveness should be checked in situ, because the cleaning efficiency is determined by the manufacturer for small medical rooms and a small number of people.

- Before installing the device, users should receive extensive training about the method of device operation and its operating conditions.

- Purifier effectiveness was influenced by room use (number of people, time spent, airing frequency).

\section{Limitations}

The research was aimed at checking whether it is possible to obtain good air quality at all with the use of a purification device. During our research, we faced the following limitations:

- The research was conducted only in two classrooms using one type of air purifying device-the small number of tested devices.

- Research should be supplemented with continuous measurement of suspended particulate matter concentrations to assess the influence of airing rooms during periods with high outdoor air pollution.

- The research should be repeated in the winter.

- It was not possible to estimate the ventilation efficiency (room air change rate).

- It was not possible to control the opening of windows by classrooms users.

- It was not possible to perform an air-tightness test. 
Supplementary Materials: The following are available online at https:/ / www.mdpi.com/article/10.3 390/atmos12121606/s1, Table S1. Number of microorganisms (CFU/ $\mathrm{m}^{3}$ ) in the classroom 04 in the morning (M) and after lessons (Al), Table S2. Number of microorganisms $\left(\mathrm{CFU} / \mathrm{m}^{3}\right)$ in the classroom 105 in the morning $(\mathrm{M})$ and after lessons $(\mathrm{Al})$, Table S3. Number of microorganisms $\left(\mathrm{CFU} / \mathrm{m}^{3}\right)$ in the external environment (research background) in the morning (M) and after lessons (Al).

Author Contributions: Conceptualization, M.B. and M.M.; data curation, M.B.; formal analysis, M.B., M.M. and K.R.; funding acquisition, M.B.; investigation, M.B. and M.M.; methodology, M.B. and M.M.; project administration, M.B.; resources, M.B. and M.M.; supervision, M.M.; visualization, M.B.; writing—original draft, M.B. and M.M.; writing—review and editing, M.B., M.M. and K.R.. All authors have read and agreed to the published version of the manuscript.

Funding: This research was funded by the Poznan University of Technology, grant number 3016/ SIGR/3335.

Institutional Review Board Statement: Not applicable.

Informed Consent Statement: Not applicable.

Conflicts of Interest: The authors declare no conflict of interest.

\section{References}

1. Mendell, M.J.; Heath, G.A. Do indoor pollutants and thermal conditions in schools influence student performance? A critical review of the literature. Indoor Air 2005, 15, 27-52. [CrossRef] [PubMed]

2. Brasche, S.; Bischof, W. Daily time spent indoors in German homes-baseline data for the assessment of indoor exposure of German occupants. Int. J. Hyg. Environ. Health 2005, 208, 247-253. [CrossRef]

3. Van der Zee, S.C.; Strak, M.; Dijkema, M.B.A.; Brunekreef, B.; Janssen, N.A.H. The impact of particle filtration on indoor air quality in a classroom near a highway. Indoor Air 2017, 27, 291-302. [CrossRef]

4. Salthammer, T.; Uhde, E.; Schripp, T.; Schieweck, A.; Morawska, L.; Mazaheri, M.; Viana, M. Children's well-being at schools: Impact of climatic conditions and air pollution. Environ. Int. 2016, 94, 196-210. [CrossRef]

5. Basińska, M.; Michałkiewicz, M.; Ratajczak, K. Impact of physical and microbiological parameters on proper indoor air quality in nursery. Environ. Int. 2019, 132, 105098. [CrossRef] [PubMed]

6. Asif, A.; Zeeshan, M.; Jahanzaib, M. Assessment of indoor and outdoor microbial air quality of cafeterias of an educational institute. Atmos. Pollut. Res. 2019, 10, 531-536. [CrossRef]

7. Madureira, J.; Paciencia, I.; Rufo, J.C.; Pereira, C.; Teixeira, J.P.; de Oliveira Fernandes, E. Assessment and determinants of airborne bacterial and fungal concentrations in different indoor environments: Homes, child day-care centres, primary schools and elderly care centers. Atmos. Environ. 2015, 109, 139-146. [CrossRef]

8. Bragoszewska, E.; Mainka, A.; Pastuszka, J.S.; Lizończyk, K.; Desta, Y.G. Assessment of Bacterial Aerosol in a Preschool, Primary School and High School in Poland. Atmosphere 2018, 9, 87. [CrossRef]

9. Kwan, S.E.; Shaughnessy, R.; Haverinen-Shaughnessy, U.; Kwan, T.A.; Peccia, J. The impact of ventilation rate on the fungal and bacterial ecology of home indoor air. Build. Environ. 2020, 177, 106800. [CrossRef]

10. WHO. Air Pollution and Child Health: Prescribing Clean Air; World Health Organization (WHO/CED/PHE/18.01): Geneva, Switzerland, 2018; Licence: CC BY-NC-SA 3.0 IGO; Available online: https:/ /www.who.int/ceh/publications/Advance-copyOct24_18150_Air-Pollution-and-Child-Health-merged-compressed.pdf?ua=1 (accessed on 28 November 2021).

11. Barrett, P.; Davies, F.; Zhang, Y.; Barrett, L. The impact of classroom design on pupils' learning: Final results of a holistic, multi-level analysis. Build. Environ. 2015, 89, 118-133. [CrossRef]

12. Mohammadyan, M.; Alizadeh-Larimi, A.; Etemadinejad, S.; Latif, M.T.; Heibati, B.; Yetilmezsoy, K.; Abdul-Wahab, S.A.; Dadvand, P. Particulate Air Pollution at Schools: Indoor-Outdoor Relationship and Determinants of Indoor Concentrations. Aerosol. Air Qual. Res. 2017, 17, 857-864. [CrossRef]

13. Gayer, A.; Adamkiewicz, Ł.; Mucha, D.; Badyda, A. Air quality health indices-Review. MATEC Web Conf. 2018, 247, 1-8. [CrossRef]

14. Naruka, K.; Gaur, J. Microbial air contamination in a school. Int. J. Curr. Microbiol. Appl. Sci. 2013, 2, 404-410. Available online: https://www.ijcmas.com/vol-2-12/Kavita\%20Naruka\%20and\%20Jyoti\%20Gaur.pdf (accessed on 28 November 2021).

15. Vornanen-Winqvist, C.; Järvi, K.; Andersson, M.A.; Duchaine, C.; Létourneau, V.; Kedves, O.; Kredics, L.; Mikkola, R.; Kurnitski, J.; Salonen, $\mathrm{H}$. Exposure to indoor air contaminants in school buildings with and without reported indoor air quality problems. Environ. Int. 2020, 141, 105781. [CrossRef] [PubMed]

16. Górzeński, R.; Szymański, M.; Mróz, T. Airtightness of Buildings in Poland. Int. J. Vent. 2014, 12, 4, 391-400. [CrossRef]

17. Kang, K.; Kim, T.; Shin, C.W.; Kim, K.; Kim, J.; Lee, Y.G. Filtration efficiency and ventilation performance of window screen filters. Build. Environ. 2020, 178, 106878. [CrossRef]

18. Kolarik, B.; Wargocki, P.; Skorek-Osikowska, A.; Wisthaler, A. The effect of a photocatalytic air purifier on indoor air quality quantified using different measuring methods. Build. Environ. 2010, 45, 1434-1440. [CrossRef] 
19. Polish Committee for Standardization. PN-89/Z-04111.02, Air Purity Protection. Microbiological Testings. Determination of the Number of Bacteria in the Atmospheric Air (Immission) with Sampling by Aspiration and Sedimentation Method; Polish Standardization Committee: Warsaw, Poland, 1989. (In Polish)

20. Polish Committee for Standardization. PN-89/Z-04111.03, Air Purity Protection. Microbiological Testings. Determination of the Number of the Fungi in the Atmospheric Air (Immission) with Sampling by Aspiration and Sedimentation Method; Polish Standardization Committee: Warsaw, Poland, 1989. (In Polish)

21. Polish Committee for Standardization. PN-EN ISO 14644-1, Cleanrooms and Associated Controlled Environments. Part 1: Classification of Air Cleanliness by Particle Concentration; Polish Standardization Committee: Warsaw, Poland, 2016.

22. Polish Committee for Standardization. PN-EN 16798-1, Energy Performance of Buildings. Ventilation for Buildings. Part 1: Indoor Environmental Input Parameters for Design and Assessment of Energy Performance of Buildings Addressing Indoor Air Quality, Thermal Environment, Lighting and Acoustics. Module M1-6; Polish Standardization Committee: Warsaw, Poland, 2019.

23. Feller, W. An Introduction to the Probability Theory and Its Application; John Wiley and sons Inc.: New York, NY, USA, 1950.

24. Basińska, M.; Michałkiewicz, M. Variability of microbial air pollution and dust concentration inside and outside a selected school in Poznań. Inżynieria Ekol. 2016, 50, 17-25. [CrossRef]

25. Polish Committee for Standardization. PN-EN 15251, Indoor Environmental Input Parameters for Design and Assessment of Energy Performance of Buildings Including Indoor Air Quality, Thermal Environment, Lighting and Acoustics; Polish Standardization Committee: Warsaw, Poland, 2012. (In Polish)

26. Andualem, Z.; Gizaw, Z.; Bogale, L.; Dagne, H. Indoor bacterial load and its correlation to physical indoor air quality parameters in public primary schools. Multidiscip. Respir. Med. 2019, 14, 2. [CrossRef]

27. Mohai, P.; Kweon, B.S.; Sangyun, L.; Ard, K. Air Pollution Around Schools Is Linked To Poorer Student Health And Academic Performance. Health Aff. 2011, 30, 852-862. [CrossRef] [PubMed]

28. Rivas, I.; Querol, X.; Wright, J.; Sunyer, J. How to protect school children from the neurodevelopmental harms of air pollution by interventions in the school environment in the urban context. Environ. Int. 2018, 121, 199-206. [CrossRef]

29. Dumała, S.M.; Dudzińska, M.R. Microbiological Indoor Air Quality in Polish Schools. Rocznik Ochrona Środowiska 2013, 15, 231-244. Available online: https://ros.edu.pl/images/roczniki/2013/pp_2013_013.pdf (accessed on 28 November 2021).

30. Du, L.; Batterman, S.; Parker, E.; Godwin, C.; Chin, J.Y.; O’Toole, A.; Robins, T.; Brakefield-Caldwell, W.; Lewis, T. Particle Concentrations and Effectiveness of Free-Standing Air Filters in Bedrooms of Children with Asthma in Detroit, Michigan. Build. Environ. 2011, 46, 2303-2313. [CrossRef]

31. Smythe, A. Effectiveness of Particle Air Purifiers in Improving the Air Quality in Classrooms in Three Urban Public Schools in the Northeastern United States, Harvard Library. 2018, pp. 1-58. Available online: http:/ /nrs.harvard.edu/urn-3:HUL.InstRepos: 37945127 (accessed on 28 November 2021).

32. Czarnecki, B.; Półrolniczak, M.; Kolendowicz, L.; Marosz, M.; Kendzierski, S.; Pilguj, N. Influence of the atmospheric conditions on PM10 concentrations in Poznań, Poland. J. Atmos. Chem. 2017, 74, 115-139. [CrossRef]

33. Basińska, M.; Ratajczak, K.; Michałkiewicz, M.; Fuć, P.; Siedlecki, M. The Way of Usage and Location in a Big City Agglomeration as Impact Factors of the Nurseries Indoor Air Quality. Energies 2021, 14, 7534. [CrossRef]

34. Ratajczak, K.; Basińska, M. The Well-Being of Children in Nurseries Does Not Have to Be Expensive: The Real Costs of Maintaining Low Carbon Dioxide Concentrations in Nurseries. Energies 2021, 14, 2035. [CrossRef]

35. Zhao, B.; Liu, Y.; Chen, C. Air purifiers: A supplementary measure to remove airborne SARS-CoV-2. Build. Environ. 2020, 177, 106918. [CrossRef] [PubMed] 